\title{
MAPEAMENTO GEOLÓGICO A SERVIÇO DA GEOLOGIA ECONÔMICA: Qual o caráter real que deve ter o mapeamento geológico, como base para a pesquisa de concentrações minerais?
}

\begin{abstract}
INTRODUÇÃO É completamente lógico e natural tratar-se sobre o aumento da atividade pesquisadora geológica no Brasil, o que é bem refletido pelas freqüentes publicações. Por exemplo, em jornal da AGECO (dezembro de 1980), G. Oitiberbet definiu um chamado: "mapeamentos básicos específicos são importantes?" Não especifica, lamentavelmente, o autor o que significa sua expressão mapeamentos básicos específicos. Se nasce uma esperança de que se trate de um mapeamento que possua metodologias específicas mais apropriadas das que temos atualmente na atividade geológica comum. Por exemplo, o boletim informativo da Sociedade Brasileira de Geologia (abril de 1980, n. 1) informa que o Departamento de Recursos Minerais (DRM) do Estado do Rio de Janeiro está encarregado da "(...) ambiciosa tarefa de mapear na escala 1:50 000 todo o Estado. Este projeto básico, de apoio ao minerador, é imprescindível ao conhecimento dos nossos recursos minerais"'. Note-se aqui a ausência de qualquer anotação de que se trate de um mapeamento específico; mas a escala 1:50 000 não precisa de nenhuma metodologia específica pois já é bem caracterizada, com metodologia bem elaborada internacionalmente.
\end{abstract}

A escala 1:50 000 é muito grande, precisa ter estudo muito detalhado, custoso, sobre todas zonas de grande complexidade geoestrutural e de cobertura (vegetal ou de sedimentos jovens). Tomemos como exemplo uma folha Paracambi. A comissão de mapeamento em escala 1:50 000 deveria ter:

1) Um geólogo diretor orientado sobre todas as hipóteses da estrutura continental onde se encontra tal folha.

2) Geólogo experiente em rochas metamórficas e, em diaftoresis, duas ou três pessoas.

3) Especialista em história quaternária, tanto montanhosa, como de planície. Com fins de estudos neotectônicos.

4) Especialistas em manifestações magmáticas, pneumatolíticas e hidrotermais (existem todos esses elementos em tal território).

5) Comissões de prospecção geofísicas:

a) sísmica de poder médio;

b) magnética aérea e magnética terrestre detalhada;

c) eletroprospecção de pouca profundidade; $\mathrm{e}$

d) talvez gravimetria, se resultar necessária durante os estudos anteriores.

6) Comissão de sondagens e poços.

7) Prospecção geoquímica em sítios a determinar durante o estudo.

8) Comissão hidrogeológica.

E lógico que não seria possível aumentar muito o número de cada comissão, posto que todas deveriam estar em um só regime de idéias gerais geológico-estruturais do referido território.

O tempo para cumprir esse mapeamento, com elaboração dos respectivos dados, seria aproximadamente de quatro a cinco anos. E o custo, em torno de dezenas de milhões de cruzeiros. Mas a grande parte desse território não resultará proveitosa no concernente a fins de mineração e, por essa razão, grandes territórios, em continentes, não são mapeados em escala 1:50 000. Escalas ainda maiores, como 1:25000 ou 1:10 000, têm outro destino para definições minerais e possuem caracteres mais de geometria descritiva.

Então o que é preciso para fazer mais real e mais veloz o mapeamento do Estado do Rio de Janeiro e não necessitar de cinqüenta anos para realizar essa tarefa?

\section{METODOLOGIA REAL DOS ESTUDOS GEOLÓGICOS PARA MINERAÇÃO}

Breves anotações.

I - Estudos não devem ser limitados pelos limites administrativos e, sim, pelos limites de estruturas e conjuntos geológicos estruturais. $\mathrm{O}$ que, conseqüentemente, indicará a ampliação do trabalho para partes dos Estados vizinhos.

II - O mapa tectônico do Brasil, editado faz um ano, deveria ser completado e chegar-se ao mapa geotectônico.

III - Um passo primeiro para tal finalidade é a elaboração rápida de um mapa geomorfológico estrutural das zonas montanhosas, e planos de manifestaçoes de mineralizações originais, vulcânicas pneumatoliticas, hidrotermais, ou de acımulações secundárias-detríticas-conglomeráticas auríferas, diamantíferas e outras.

Como base topográfica para o desenvolvimento desses estudos, podem-se perfeitamente utilizar-se os mapas topográficos existentes na escala 1:200 000. É preciso destacar que Geomorfologia Estrutural e Geomorfologia Dinâmica são atualmente os mais econômicos e mais eficientes métodos de pesquisa para todos os tipos de mineralização, inclusive na pesquisa de hidrocarbonetos.

A confecção de mapa Geomorfológico Estrutural demanda espaço de tempo muito curto, creio, mobilizando experientes geólogos. Dentro de um ano este mapa pode ser concluido.

IV - Um outro passo de importância presente e que pode ser estudado simultaneamente com o primeiro é o mapeamento de alinhamentos destrutivos que ocorrem nas maiores drenagens dos fluidos tanto mineralizadores quanto de hidrocarbonetos. $E$ preciso destacar também que, na atualidade (e sobretudo no Brasil), o papel dos hidrocarbonetos profundos adquire maior popularidade.

V - Determinados alinhamentos destrutivos, especialmente nos falhamentos, devem ser estudados geoquimicamente, o que determinará falhas profundas, portadoras dos fluidos diversos, que, devido a certas condições físicas, podem dar concentrações minerais desejadas pelo homem. 
VI - Só depois de essas determinações se apresentarem evidentes poderão ser diagnosticados e determinados sitios onde escalas maiores poderão ser aplicadas como mapeamento geológico. Logicamente, nem todos territórios dos Estados precisam ser cobertos com esses mapeamentos.

CONCLUSÃo O Estado do Rio de Janeiro, faz pouco tempo, foi mapeado por dados de fotografias aéreas do Landsat I, em escala 1:400 000. Esse valioso passo, primeiro, oferece as possibilidades de análises profundas sobre a estruturação do Estado, sobretudo se for completado (o que é fácil de fazer) por morfologia para confeccionar o Mapa Geomorfológico. Estrutural do Estado' do Rio de janeiro, em escala 1:200 000.

Mas o mapeamento projetado em escala 1:50 000 apresenta um grande "salto" em escala (oito vezes). O trabalho será de elevado custo se se empregarem metodologias definidas internacionalmente. Permito-me citar um caso que tais metodologias não foram cumpridas nem sequer a um nível mínimo razoável - o mapa geológico da folha de Santa Cruz, que pude conhecer de perto e não mais detalhado que o citado mapa de 1:400 000, e em alguns casos com erros imperdoáveis.
Então existem evidentemente diferentes interpretações em sentido de escalas de mapeamento propriamente geológico. O método de comparação é muito efetivo e me permito citar um outro caso - os estudos geológicos de parte do oeste da península Kamchatka. O relatório comenta a afirmação que o território dado é bem estudado: o territorio foi coberto todo por mapeamento geologico em escala 1:200 000 e, parcialmente, em apenas alguns sitios em escalas maiores. Além do que foram efetuados grandes quantidades de prospeç̧ões geofísicas, geoquímicas e sondagens.

Por último, permito-me afirmar que o mapeamento geológico é um termo muito lacônico e não reflete completamente o caráter da tarefa. Praticamente, na atualidade, o fim do mapeamento geológico adquire o caráter muito universal, praticamente como alcance de ser o mapeamento geotectônico. A parte dos integrantes geológicos joga o papel da documentação que deve ser interpretada em sentido dinâmico, ou geotectônico.

Simon Wladimir Burmistrov, Universidade Federal, Rural do Rio de Janeiro 